\title{
Perceived Value dan Loyalitas Pengguna Kartu Kredit: Peran Kepuasan Sebagai Variabel Pemediasi
}

\author{
Dhian Wahyuni, Ihsanuddin \\ Sekolah Tinggi Ilmu Ekonomi Sabang, Banda Aceh \\ AMIK Indonesia, Banda Aceh
}

\begin{abstract}
The research study aims to investigate the effect of perceived value on customer satisfaction and its impact on the behavioral loyalty of commercial bank credit card users in Banda Aceh. The research sample are 132 credit card users taken by random sampling. Data collection uses a questionnaire, and then the data is analyzed by statistical means of structural equation model (SEM) AMOS 21. The study found that perceived value has a positive and significant effect on satisfaction and loyalty of commercial bank credit card users. The satisfaction also has a positive and significant effect on loyalty of credit card users. The existence of satisfaction strengthens the influence of perceived value on loyalty of credit card users. The mediating effect of satisfaction as an intervening variable between the perceived value and loyalty is partial mediation.
\end{abstract}

Keywords: Loyalty, Satisfaction, Perceived Value, and Structural Equation Model.

\section{PENDAHULUAN}

Keberadaan lembaga keuangan bank sangat penting artinya bagi pembangunan ekonomi. Perannya sebagai institusi yang menyelenggarakan layanan jasa keuangan bagi masyarakat diyakini dapat memberikan dampak signifikan bagi perbaikan indikator makro ekonomi seperti peningkatan pendapatan, penciptaan lapangan kerja, penurunan tingkat kemiskinan dan pengurangan ketimpangan pendapatan secara umum (Amri dan Nazamudin, 2018). Karena itu, keberadaan lembaga keuangan dengan seluruh layanan jasa keuangan yang diberikannya untuk mendorong pembangunan ekonomi harus dapat ditingkatkan dari waktu ke waktu. Peningkatan kualitas pelayanan menjadi perhatian bagi setiap lembaga keuangan bank. Bank dengan kualitas pelayanan yang baik berupaya melakukan inovasi pelayanan untuk memudahkan nasabahnya memanfaatkan layanan jasa keuangan. Bank yang tidak mampu memberikan pelayanan terbaik, akan ditinggalkan oleh nasabahnya. Kondisi tersebut tentunya tidak hanya berdampak pada citra bank tersebut, tetapi dapat berpengaruh pada kinerja bank secara keseluruhan. Apalagi bank pada dasarnya hanya sebagai lembaga perantara antara nasabah tabungan dan nasabah kredit/pembiayaan (Amri et al., 2018). Guna meningkatkan kualitas pelayanan guna memenuhi kebutuhan nasabah, bank umum di Banda Aceh berupaya menyediakan produk layanan dalam bentuk kartu kredit. Tujuannya adalah untuk memberikan kemudahan bagi nasabah dalam melakukan kegiatan transaksi keuangan.

Hingga saat ini penggunaan kartu kredit bank umum oleh sebagian nasabah sudah sangat familiar dan dinilai sangat bermanfaat bagi mereka. Kenyataannya, hasil survei awal yang peneliti lakukan melalui wawancara dengan sejumlah pengguna kartu kredit bank umum di Banda Aceh mengindikasikan bahwa perilaku mereka dalam menggunakan kartu kredit. Ada di antara nasabah yang selalu menggunakan kartu kredit bank umum tertentu dalam berbagai kegiatan transaksi. nasabah yang termasuk dalam kelompok ini hanya memiliki satu kredit. Namun di sisi lain tidak sedikit di antara mereka merasa tidak cukup dengan penggunaan satu kartu kredit. Bahkan mereka yang termasuk dalam kelompok ini memiliki pengalaman berganti-ganti kartu kredit. Sebagai contoh, ada nasabah yang menggunakan kartu kredit bank umum syariah dan kartu kredit bank umum dalam waktu yang sama. Selain itu juga ada diantara pengguna kartu kredit yang sebelumnya menggunakan kartu kredit bank umum syariah, justru berpindah menggunakan kartu kredit bank konvensional atau sebaliknya. Fenomena ini menjadi bukti empiris awal tentang adanya persoalan loyalitas penggunaan kartu kredit dikalangan nasabah. Loyalitas yang dimaksudkan dalam kajian ini adalah loyalitas keperilakuan. Loyalitas keperilakuan berkaitan dengan loyalitas seseorang yang dikaitkan dengan penilaiannya terhadap harga yang harus mereka bayar, kemudahan dan kenyamanan dalam memperoleh suatu produk. Hal ini mengindikasikan bahwa loyalitas keperilakuan pada dasarnya terkait dengan hasil evaluasi konsumen terhadap suatu produk (Neal, 2010). Darsono (2014) menyatakan bahwa loyalitas keperilakuan direfleksikan oleh probabilitas terjadinya tindakan pembelian, runtutan pembelian serta proporsi pembelian. 
Dhian Wahyuni dan Ihsanuddin, Perceived Value dan Loyalitas Pengguna Kartu Kredit: Peran Kepuasan Sebagai Variabel Pemediasi

Loyalitas seseorang pengguna kartu kredit tentunya dapat dipengaruhi oleh kepuasan yang diperolehnya dari penggunaan kartu kredit tersebut. Kepuasan konsumen dapat diartikan sebagai perasaan positif secara keseluruhan tentang pelayanan yang diberikan oleh produsen (Yang \& Peterson, 2014). Adanya keterkaitan antara loyalitas dengan kepuasan konsumen seperti dikemukakan oleh Khan \& Kadir (2011) dan Dehghan et al. (2015) bahwa kepuasan konsumen mempengaruhi loyalitas konsumen. Semakin baik customer satisfaction akan semakin tinggi loyalitas konsumen. Selain itu, loyalitas konsumen juga dapat dipengaruhi oleh perceived value. Customer perceived value adalah perbandingan dari hasil yang didapat konsumen dengan hasil produksi produsen. Konsep persamaan ini mengacu pada evaluasi konsumen terhadap apa yang adil, benar, atau pantas terhadap biaya yang dikeluarkan oleh konsumen, jadi perceived value dilihat dari hasil evaluasi manfaat dan pengorbanan yang dilakukan terhadap sesuatu yang ditawarkan. Pengorbanan ini dapat berbentuk moneter dan non-moneter seperti waktu dan energi yang terpakai (Yang \& Peterson, 2014). Adanya keterkaitan antara perceived value dengan loyalty seperti ditemukan oleh Anuwichanont dan Mechinda (2016), Shanmugam et al. (2014), Asy'ari (2014) dan Picon-Berjoyo et al. (2016) bahwa perceived value tidak hanya mempengaruhi customer satisfaction tetapi juga berdampak pada loyalitas pelanggan.

Hasil survei awal terhadap sejumlah pengguna kartu kredit bank umum di Banda Aceh mengindikasikan bahwa kepuasan mereka dalam menggunakan kartu tersebut relatif berbeda satu sama lain. Selain itu, perceived value (nilai yang mereka persepsikan) sehubungan dengan eksistensi kartu tersebut juga relatif berbeda. Seperti dijelaskan sebelumnya, baik kepuasan maupun perceived value secara teoritis dan empiris dapat berpengaruh terhadap loyalitas konsumen. Sehingga kajian mengenai keterkaita antara ketiga variabel tersebut dinilai penting sebagai dasar pertimbangan bank dalam meningkatkan loyalitas nasabah dalam menggunakan kartu kredit. Karena itu, penelitian ini bertujuan untuk menganalisis pengaruh perceived value terhadap loyalitas pengguna kartu kredit tersebut dengan menggunakan kepuasan konsumen sebagai variabel pemediasi.

\section{Literature Review dan Pengembangan Hipotesis Loyalitas}

Loyalitas dapat diartikan sebagai ketetapan hati untuk melakukan pembelian atau berlangganan produk atau jasa secara tetap di masa yang akan datang (Oliver, 2017). Selanjutnya Kotler \& Keller (2016) berpendapat bahwa loyalitas pelanggan identik dengan komitmen untuk berlangganan kembali produk atau jasa tertentu di masa yang akan datang, kendatipun terdapat pengaruh situasional akibat adanya usaha pemasaran yang memiliki potensi dapat mendorong perubahan perilaku pembeli. Loyalitas berkaitan dengan alternatif pilihan yang dilakukan oleh konsumen untuk membeli barang dan jasa dengan merek tertentu dibandingkan dengan merek lainnya dalam kelompok produk yang sama (Giddens \& Hofmaan, 2012). Schiffman \& Kanuk (2014) menyatakan bahwa loyalitas dapat dilihat sebagai preferensi konsumen untuk membeli produk dan jasa dengan merek yang sama dalam katagori kelompok produk dan jasa tertentu. Namun demikian, terdapat perbedaan antara loyalitas konsumen dengan perilaku pembelian secara berulangulang. Perilaku pembelian berulang (repeat purchasing behavior) pada dasarnya adalah adalah tindakan pembelian secara berulang-ulang terhadap produk atau merek tertentu yang lebih cenderung terdorong oleh faktor kebiasaan. Sedangkan dalam kaitannya dengan loyalitas konsumen, tindakan pembelian ulang terhadap produk dan jasa lebih ditentukan oleh kesetiaan merek sebagai diterminan utamanya (Amri, 2013).

\section{Loyalitas Konsumen dan Faktor-faktor yang Mempengaruhinya}

Loyalitas yang dimaksudkan dalam kajian ini adalah loyalitas keperilakuan, yaitu loyalitas yang timbul akibat adanya perubahan harga, perubahan lokasi/tempat memperoleh produk sehingga dianggap lebih nyaman bagi konsumen dan loyalitas yang disebabkan oleh adanya hasil evaluasi benefit oleh konsumen (Neal, 2010). Loyalitas tersebut dapat dipahami sebagai konsep yang memberikan penekanan pada rentetan peristiwa pembelian, proposi pembelian dan kemungkinan melakuka pembelian (Darsono, 2014). Pendekatan keperilakuan memiliki asumsi bahwa pembelian yang dilakukan terhadap suatu merek tertentu dalam periode waktu tertentu merupakan sinyalemen penting yang mengindikasikan adanya loyalitas. Asy’ari (2014) memiliki pandangan bahwa loyalitas keperilakuan lebih mengarah pada pembelian secara berulang dan juga kemauan pelanggan untuk merekomendasikan produk kepada teman-teman 
Dhian Wahyuni dan Ihsanuddin, Perceived Value dan Loyalitas Pengguna Kartu Kredit: Peran Kepuasan Sebagai Variabel Pemediasi

mereka. Loyalitas keperilakuan dapat dipengaruhi oleh sejumlah faktor antara lain kepuasan konsumen dan perceived value. Adanya pengaruh kedua faktor tersebut terhadap loyalitas didukung hasil penelitian sejumlah peneliti seperti Khan \& Kadir (2011), Amri (2013), Yang \& Peterson (2014), dan Dehghan et al. (2015) yang memberikan kesimpulan bahwa kepuasan konsumen dan perceived value berpengaruh terhadap loyalitas keperilakuan. Sebelumnya, penelitian Ball et al. (2004) dan Forouzandeh \& Ahmadi (2010) juga menyajikan bukti empiris bahwa loyalitas konsumen terhadap suatu produk dipengaruhi secara signifikan oleh kepuasan mereka menggunakan produk tersebut serta harapan mereka sehubungan dengan penggunaan produk tersebut.

\section{Kepuasan Konsumen}

Kepuasan konsumen berhubungan dengan perasaan mereka setelah melakukan pembelian suatu produk (Kotler \& Keller, 2016:46). Dalam hal ini, tingkat kepuasan seseorang konsumen sangat ditentukan oleh sejauhmana suatu produk dapat memenuhi kebutuhan mereka. Hal ini disebabkan, kepuasan pada dasarnya merupakan perbandingan antara harapan terhadap suatu produk dengan kenyataan yang dirasakan konsumen setelah mereka mengkonsumsi produk tersebut. Harapan terhadap produk muncul dari dari pengalaman dan informasi yang diperoleh konsumen mengenai segala sesuatu yang berkaitan dengan atribut produk termasuk kegunaan dan kemampuan produk dalam memenuhi kebutuhan mereka. Ketika kenyataan yang mereka rasakan belum sesuai dengan harapan mereka, maka dalam kondisi tersebut akan muncul ketidakpuasan. Sebalikya ketika kenyataan yang mereka rasakan sesuai dengan harapan, maka muncul kepuasan. Sebagaimana pendapat Yang \& Peterson (2014) yang menyatakan bahwa kepuasan konsumen merupakan sebagai perasaan positif atau negatif dalam diri konsumen setelah mereka mengkonsumsi suatu produk. Perasaan positif dimaksud dalam hal ini dapat diartikan sebagai perasaan konsumen yang puas setelah mengkonsumsi suatu produk. Selanjutnya perasaan negatif identik dengan ketidakpuasan.

\section{Perceived Value}

Perceived value dalam diri konsumen dapat diartikan sebagai penilaian mereka terhadap kegunaan suatu produk yang didasarkan pada persepsi tentang manfaat yang akan mereka dan pengorbanan yang akan mereka lakukan untuk memperoleh produk tersebut (Koupai et al., 2015). Sebelumnya, Yang \& Peterson (2014) berpendapat bahwa perceived value merupakan perbandingan antara manfaat yang diperoleh konsumen dari penggunaan produk dengan manfaat yang diperoleh produsen dari proses produksi produk tersebut. Konsep ini mengacu pada evaluasi konsumen tentang pengorbanan yang harus mereka lakukan untuk memperoleh produk. Pengorbanan yang dimaksudkan tidak hanya dalam bentuk satuan moneter seperti harga yang harus mereka bayarkan, tetapi juga dalam bentuk non moneter seperti waktu dan energi yang mereka keluarkan untuk mendapatkan produk. Hal ini didukung oleh pendapat Kotler \& Keller (2016) yang menyatakan bahwa customer perceived value pada dasarnya adalah gap antara evaluasi konsumen atas semua benefit atau keuntungan yang mereka harapkan serta semua biaya yang mereka keluarkan dan alternatif-alternatif lainnya yang ada dalam pikiran mereka.

\section{Keterkaitan antar Variabel}

\section{Pengaruh Perceived Value terhadap Kepuasan Konsumen}

Perceived value dapat berpengaruh terhadap kepuasan konsumen. Hal ini dapat dijelaskan bahwa perceived value pada dasarnya merupakan nilai-nilai yang diharapkan konsumen dari suatu produk. Ketika nilai yang mereka peroleh sesuai dengan harapan mereka, maka konsumen akan cenderung puas dalam menggunakan produk yang mereka pilih. Secara empiris, adanya pengaruh perceived value terhadap kepuasan konsumen ditemukan oleh Anuwichanont dan Mechinda (2016) bahwa perceived value berpengaruh positif dan signifikan terhadap kepuasan konsumen. Dehghan et al. (2015) juga membuktikan adanya pengaruh perceived value terhadap kepuasan konsumen. Mengacu pada uraian di atas, maka hipotesis pertama penelitian ini dinyatakan sebagai berikut:

$\mathrm{H}_{1}$ : Perceived value berpengaruh terhadap kepuasan pengguna kartu kredit 
Dhian Wahyuni dan Ihsanuddin, Perceived Value dan Loyalitas Pengguna Kartu Kredit: Peran Kepuasan Sebagai Variabel Pemediasi

\section{Pengaruh Perceived Value terhadap Loyalitas Konsumen}

Loyalitas konsumen dapat dipahami sebagai konsep yang menekankan pada runtutan pembelian, proporsi pembelian, dan probabilitas pembelian (Darsono, 2014). Loyalitas keperilakuan lebih disebabkan karena adanya perubahan harga, lokasi yang nyaman dari seorang pembeli, dan berdasarkan evaluasi benefit (harga miring) (Neal, 2010). Perceived value dapat berpengaruh terhadap loyalitas konsumen. Hal ini dapat dijelaskan bahwa perceived value pada dasarnya merupakan nilai-nilai yang diharapkan konsumen dari suatu produk. Ketika nilai yang mereka peroleh sesuai dengan harapan mereka, maka konsumen akan cenderung menggunakan produk tersebut secara berulang-ulang, sehingga membentuk loyalitas konsumen. Secara empiris, adanya pengaruh perceived value terhadap loyalitas konsumen dibuktikan oleh PiconBerjoyo et al. (2016) bahwa perceived value berpengaruh positif dan signifikan terhadap loyalitas konsumen. Sebelumnya penelitian Khan \& Kadir (2011) juga memberikan kesimpulan yang sama bahwa loyalitas konsumen dipengaruhi oleh perceived value. Mengacu pada uraian di atas, maka hipotesis kedua penelitian ini dinyatakan sebagai berikut:

$\mathrm{H}_{2}$ : Perceived value berpengaruh terhadap loyalitas pengguna kartu kredit.

\section{Pengaruh Kepuasan terhadap Loyalitas}

Kepuasan dan loyalitas saling terkait satu sama lain, tetapi keduanya memiliki perbedaan yang sanga jelas (Ball et al., 2004). Kepuasan merupakan salah satu faktor penentu loyalitas (Forouzandeh \& Ahmadi, 2010). Konsumen yang puas terhadap produk tertentu akan cenderung menggunakan produk tersebut di masa yang akan datang. Sehingga semakin tinggi kepuasan yang diperoleh oleh konsumen akan semakin tinggi pula loyalitas dalam menggunakan produk tersebut. Artinya, konsumen yang menemukan kepuasan dalam menggunakan suatu produk akan memiliki perilaku loyal terhadap produk tersebut. Adanya keterkaitan antara loyalitas dengan kepuasan konsumen secara empiris dibuktikan oleh Khan \& Kadir (2011) dan Dehghan et al. (2015) bahwa kepuasan konsumen berpengaruh positif dan signifikan terhadap loyalitas konsumen. Sebelumnya hasil penelitian Beerli et al. (2014) juga menyimpulkan bahwa kepuasan berdaampak positif positif terhadap loyalitas konsumen. Mengacu pada uraian di atas, maka hipotesis ketiga dinyatakan sebagai berikut:

$\mathrm{H}_{3}$ : Kepuasan konsumen berpengaruh terhadap loyalitas pengguna kartu kredit.

\section{Pengaruh Perceived Value terhadap Loyalitas Melalui Kepuasan Konsumen.}

Pengaruh perceived value terhadap loyalitas konsumen dapat terjadi secara langung maupun tidak langsung melalui kepuasan sebagai variabel perantara. Hal ini disebabkan, berbagai temuan empiris seperti dijelaskan sebelumnya menemukan bahwa perceived value berpengaruh terhadap kepuasan konsumen. Selanjutnya kepuasan konsumen berpengaruh terhadap loyalitas. Secara empiris, pengaruh tidak langsung perceived value terhadap loyalitas konsumen sudah dibuktikan oleh Picon-Berjoyo et al. (2016) bahwa kepuasan memediasi pengaruh perceived value terhadap loyalitas konsumen. Temuan tersebut konsisten dengan temuan sebelumnya yang dilakukan oleh Lam et al., (2014), Lin et al. (2015) dan Picon et al. (2014) bahwa pengaruh perceived value terhadap loyalitas dapat terjadi melalui kepuasan konsumen. Mengacu pada uraian di atas, maka hipotesis keempat dinyatakan sebagai berikut:

$\mathrm{H}_{4}$ : Perceived value berpengaruh terhadap loyalitas pengguna kartu kredit melalui kepuasan sebagai variabel pemediasi.

\section{METODE}

Penelitian dilakukan terhadap pengguna kartu kredit bank umum di Banda Aceh. Pada awalnya sampel penelitian direncanakan sebanyak 140 orang dengan alasan bahwa untuk penelitian persepsi, jumlah sampel lebih dari 100 sudah dianggap mencukupi (Amri, 2013). Namun pada saat pengumpulan data sebagian kuesioner dinyatakan rusak dikarenakan tidak lengkap terisi sehingga tidak layak diolah dan dianalisis. Akhirnya jumlah sampel yang sebenarnya hanya 132 orang pengguna kartu kredit. Mereka berasal dari dua kelompok bank umum yakni Bank Umum Syariah dan Bank Umum Konvensional. Data dikumpulkan melalui penyebaran kuesioner yang berisi sejumlah pernyataan yang dikembangkan dari indikator masing-masing variabel. Seperti halnya variabel loyalitas pengguna kartu kredit, pengukuran variabel tersebut menggunakan lima indikator meliputi: (1) sensitifitas pengguna terhadap biaya penggunaan 
Dhian Wahyuni dan Ihsanuddin, Perceived Value dan Loyalitas Pengguna Kartu Kredit: Peran Kepuasan Sebagai Variabel Pemediasi

kartu kredit, (2) sensitifitas pengguna terhadap promosi kartu kredit, (3) keseringan menggunakan kartu kredit, (4) frekuensi penggunaan kartu kredit, dan (5) kemauan untuk merekomendasikan kartu kredit kepada orang lain. Selanjutnya pengukuran kepuasan konsumen didasarkan pada lima indikator terdiri dari: (1) kemampuan kartu kredit memenuhi kebutuhan pengguna, (2) persepsi perbandingan kartu kredit dengan kartu kredit lain, (3) layanan karyawan bank ketika munculnya komplain sehubungan dengan penggunaan kartu kredit, (4) penilaian pengguna kartu kredit terhadap pelayanan bank, dan (5) pengalaman penggunaan kartu kredit. Terakhir, pengukuran perceived value juga menggunakan lima indikator terdiri dari: (1) kemampuan kartu kredit memuaskan kebutuhan, (2) penilaian terhadap manfaat kartu kredit, (3) perbandingan manfaat penggunaan kartu kredit dibandingkan dengan kartu kredit lain, (4) harapan terhadap kemampuan bank dalam meningkatkan kualitas kartu kredit, dan (5) persepsi manfaat kartu kredit dibandingkan biaya penggunaan.

Mengingat variabel yang dioperasionalkan dalam penelitian ini adalah variabel kualitatif, diperlukan adanya proses kuantifikasi variabel tersebut sehingga dapat dianalisis dengan menggunakan peralatan statistik. Proses kunatifikasi tersebut dilakukan dengan memberikan skala terhadap pilihan jawaban (tingkat kesetujuan) yang disediakan untuk masing-masing pernyataan pada setiap variabel penelitian (Amri \& Surya, 2013). Skala Likert dengan skor berkisar antara 1-5. Pemberian skor berdasarkan tingkat kesetujuan berlaku ketentuan 1 = sangat tidak setuju, $2=$ tidak setuju, $3=$ kurang setuju, $4=$ setuju dan $5=$ sangat setuju. Sesuai dengan kerangka penelitian yang telah dijelaskan dalam Gambar 1 sebelumnya dapat dipahami bahwa kepuasan konsumen merupakan fungsi dari perceived value, dan selanjutnya loyalitas pengguna kartu kredit merupakan fungsi dari kepuasan konsumen dan perceived value. Sehingga keberadaan kepuasan konsumen merupakan intervening variabel terhadap hubungan perceived value dan loyalitas pengguna kartu kredit.

Peralatan analisis data yang digunakan dalam penelitian ini adalah structural equation model (SEM) yang dioperasionalkan dengan software AMOS (Analysis of Moment Structure) versi 21. Penggunaan SEM sebagai alat analisis data melalui beberapa tahapan analisis terdiri dari confirmatory factor analysis (CFA) dan kemudian dilanjutkan dengan full structural model. CFA didesain untuk menguji multimensionalitas dari suatu konstruk teoritis. Analisis ini sering juga disebut menguji validitas konstruk teoritis. Dengan kata lain, analisis konfirmatori menguji apakah indikator-indikator yang digunakan dalam setiap variabel penelitian (konstruk) dinyatakan valid untuk mengukur konstruk tersebut (Ghozali, 2011). Dalam CFA dilakukan uji signifikansi bobot faktor dan uji kesesuaian model (good of fit test). Uji signifikansi bobot faktor dimaksudkan untuk menguji apakah masing-masing indikator dinyatakan valid untuk mengukur konstruk. Tolok ukur yang digunakan adalah nilai loading factor. Nilai yang dipersyaratkan minimal 0,70. Apabila nilai loading factor suatu indikator lebih kecil dari 0,70 maka indikator tersebut dinyatakan tidak valid untuk mengukur konstruk (Ghozali, 2011). Tolok ukur lainnya dalam menilai signifikansi bobot faktor adalah critical ratio (CR). Hal ini dimaksudkan untuk mengukur apakah indikator-indikator pada setiap konstruk secara signifikan merupakan dimensi dari konstruk tersebut, dengan ketentuan apabila CR $>2,00$ dan $p$-value $<0,05$ dapat diartikan bahwa indikator-indikator tersebut secara signifikan merupakan dimensi dari konstruk yang diukur.

Uji kesesuaian model (good of fit test) dimaksudkan untuk menguji apakah model pengukuran didesain dalam mengukur suatu variabel atau konstruk dapat dikatakan cocok untuk mengukur variabel atau kontruk tersebut. Tolok ukur good of fit test didasarkan pada indek pengujian kelayakan (goodness of fit index) terdiri dari $\mathrm{X}^{2}$ atau chi-square statistik, RMSEA (Root Mean Square Error of Appoximation), GFI (Goodness of Fit Index), AGFI (Adjusted Goodness of Fit Index) TLI (Tucker Lewis Index) dan CFI (Comparative Fit Index). Pengujian signifikansi pengaruh langsung antar variabel sebagai dasar penolakan atau penerimaan hipotesis didasarkan pada nilai $p$-value yang dihasilkan melalui peralatan statistik multivariat SEM. Jika suatu variabel eksogen tertentu memiliki nilai $p$-value $<0.05$ berarti variabel tersebut berpengaruh signifikan (hipotesis diterima). Sebaliknya jika nilai $p$-value $>0.05$ berarti variabel tersebut tidak berpengaruh signifikan (hipotesis ditolak). Selanjutnya pengujian pengaruh tidak langsung yang menempatkan kepuasan konsumen sebagai variabel pemediasi antara perceived value dan loyalitas pengguna kartu kredit, merujuk pada pendapat Baron dan Kenny (1986) yang berargumen bahwa pengaruh mediasi akan wujud ketika terdapat 4 kriteria berikut: (1) Variabel eksogen mempengaruhi variabel endogen, (2) Variabel eksogen mempengaruhi variabel pemediasi, (3) Variabel pemediasi harus 
Dhian Wahyuni dan Ihsanuddin, Perceived Value dan Loyalitas Pengguna Kartu Kredit: Peran Kepuasan Sebagai Variabel Pemediasi

mempengaruhi variabel endogen dan (4) Full/Perfect Mediation akan wujud ketika pengaruh variabel eksogen terhadap variabel endogen secara langsung adalah tidak signifikan, tapi pengaruh tersebut signifikan ketika mengikutsertakan variabel mediasi, selanjutnya partial mediation terjadi ketiga pengaruh variabel eksogen terhadap variabel endogen adalah signifikan, baik melibatkan variabel pemediasi maupun tanpa variabel pemediasi.

\section{HASIL}

\section{Confirmatory Factor Analysis dan Measurement Model}

Penelitian ini, variabel atau konstruk yang diteliti terdiri dari perceived value, kepuasan dan loyalitas pengguna kartu kredit. Analisis konfirmatori dimaksudkan untuk menguji apakah indikator-indikator yang digunakan untuk mengukur masing-masing variabel mampu memanifestasikan variabel yang diukur. Dengan kata lain, analisis CFA ini juga berguna untuk menentukan apakah suatu indikator pengukuran yang digunakan untuk mengukur variabel dinyatakan valid atau tidak. Secara statistik, suatu indikator dapat dinyatakan sebagai manifestasi dari variabel yang diukur apabila memiliki nilai loading factor $>0,70$, nilai critical ratio (CR) > 2,00 dan p-value < 0,05 (Ghozali, 2011). Ketika suatu indikator tidak memenuhi kriteria tersebut, maka indikator tersebut direduksi dari model dan kemudian uji CFA dilanjutkan pada tahap selanjutnya hingga semua indikator atau variabel manifest tersebut memenuhi kriteria yang telah ditentukan. Uji CFA dalam penelitian ini dilakukan dua tahap. Hal ini disebabkan pada tahap pertama, masih ada indikator yang tidak memenuhi syarat, yakni indikator kelima yang berkaitan dengan perceived value (PV5) dengan loading factor sebesar 0,689. Kemudian indikator tersebut direduksi dan uji CFA dilanjutkan pada tahap kedua. Hasil uji CFA tahap pertama dan kedua seperti ditunjukkan dalam Tabel 1.

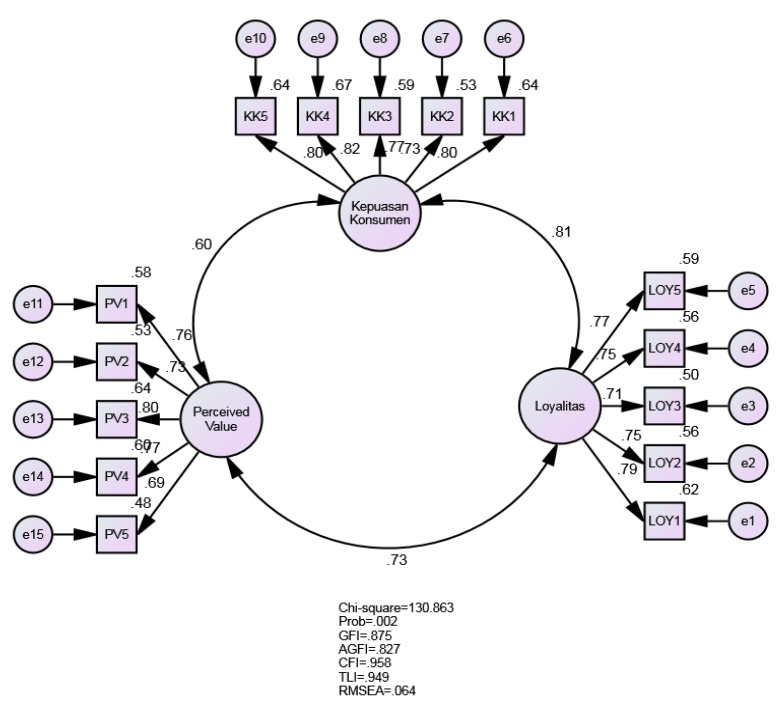

Gambar 1. Hasil CFA Tahap Pertama

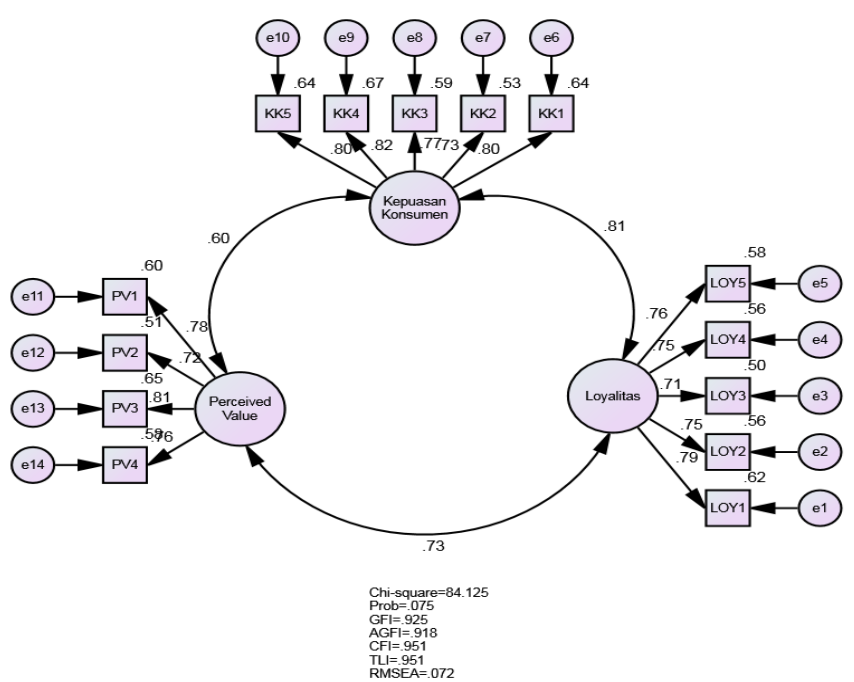

Gambar 2. Hasil CFA Tahap Kedua

Tabel 1.

Hasil Confirmatory Factor Analysis Tahap Pertama

\begin{tabular}{|c|c|c|c|c|c|c|c|c|}
\hline & & & \multicolumn{3}{|c|}{ Uji CFA Tahap Pertama } & \multicolumn{3}{|c|}{ Uji CFA Tahap Kedua } \\
\hline & & & $\begin{array}{c}\text { Loading } \\
\text { Factor }\end{array}$ & $\begin{array}{c}\text { Critical } \\
\text { Ratio }\end{array}$ & p-value & $\begin{array}{c}\text { Loading } \\
\text { Factor }\end{array}$ & $\begin{array}{c}\text { Critical } \\
\text { Ratio }\end{array}$ & p-value \\
\hline KK5 & $\begin{array}{ll}<-- \\
\end{array}$ & Kepuasan_Konsumen & .802 & & & .802 & & \\
\hline KK4 & $<---$ & Kepuasan_Konsumen & .820 & 10.074 & $* * *$ & .820 & 10.081 & $* * *$ \\
\hline KK3 & $<---$ & Kepuasan_Konsumen & .770 & 9.291 & $* * *$ & .769 & 9.287 & $* * *$ \\
\hline KK2 & $<---$ & Kepuasan_Konsumen & .729 & 8.672 & $* * *$ & .729 & 8.673 & $* * *$ \\
\hline KK1 & $<---$ & Kepuasan_Konsumen & .802 & 9.790 & $* * *$ & .802 & 9.797 & $* * *$ \\
\hline PV5 & $<--$ & Perceived_Value & .689 & & & & & \\
\hline PV4 & $<---$ & Perceived_Value & .772 & 7.651 & $* * *$ & .761 & 8.406 & $* * *$ \\
\hline PV3 & $<---$ & Perceived_Value & .800 & 7.881 & $* * *$ & .807 & 8.920 & $* * *$ \\
\hline PV2 & $<---$ & Perceived_Value & .729 & 7.273 & $* * *$ & .716 & 7.870 & $* * *$ \\
\hline
\end{tabular}


Dhian Wahyuni dan Ihsanuddin, Perceived Value dan Loyalitas Pengguna Kartu Kredit: Peran Kepuasan Sebagai Variabel Pemediasi

\begin{tabular}{|c|c|c|c|c|c|c|c|c|}
\hline PV1 & $<---$ & Perceived_Value & .759 & 7.535 & $* * *$ & .775 & & \\
\hline LOY5 & $<---$ & Loyalitas & .766 & & & .764 & & \\
\hline LOY4 & $<---$ & Loyalitas & .749 & 8.465 & $* * *$ & .749 & 8.448 & $* * *$ \\
\hline LOY3 & $<---$ & Loyalitas & .706 & 7.923 & $* * *$ & .706 & 7.906 & $* * *$ \\
\hline LOY2 & $<---$ & Loyalitas & .748 & 8.456 & $* * *$ & .748 & 8.437 & $* * *$ \\
\hline LOY1 & $<---$ & Loyalitas & .789 & 8.981 & $* * *$ & .790 & 8.967 & $* * *$ \\
\hline
\end{tabular}

Sumber: Data Primer (Diolah), 2019

Berdasarkan Tabel 1 di atas dapat dilihat bahwa semua kriteria pengujian confirmatory factor analysis (CFA) sudah terpenuhi, dimana semua indikator memiliki nilai loading factor di atas 0,70, nilai critical ratio $(\mathrm{CR})$ di atas 2,00 dan p-value di bawah 0,05. Artinya indikator-indikator pada setiap variabel seperti ditunjukkan dalam tersebut adalah indikator-indikator yang mampu mengkonfirmasi variabel yang diteliti. Sesuai dengan tahapan CFA, uji terhadap measurement model juga dilakukan dua tahap. Untuk lebih jelasnya mengenai measurement model tahap pertama dan kedua seperti ditunjukkan dalam Tabel 2.

Tabel 2.

Hasil Measurement Model

\begin{tabular}{lllll}
\hline $\begin{array}{l}\text { Tahapan } \\
\text { Pengujian }\end{array}$ & Goodness-of-Fit Index & Kriteria Nilai & Hasil & Evaluasi Model \\
\hline & $\chi^{2}-$ Chi-square & $\mathrm{X}^{2}{ }_{\text {hit }}<\mathrm{X}^{2}$ tab & $30,863>104,773$ & Belum baik \\
& Probability & $\geq 0,05$ & 0,002 & Belum baik \\
Tahap Pertama & $\geq 0,90$ & 0,875 & Belum baik \\
& GFI & $\geq 0,90$ & 0,827 & Belum baik \\
& AGFI & $\geq 0,95$ & 0,958 & Baik \\
& TLI & $\geq 0,95$ & 0,949 & Belum baik \\
& CFI & $\leq 0,08$ & 0,064 & Baik \\
& RMSEA & $\mathrm{X}^{2}$ hit $<\mathrm{X}^{2}$ tab & $, 125<95,081$ & Baik \\
& $\chi^{2}-$ Chi-square & $\geq 0,05$ & 0,075 & Baik \\
& Probability & $\geq 0,90$ & 0,925 & Baik \\
& GFI & $\geq 0,90$ & 0,918 & Baik \\
& AGFI & $\geq 0,95$ & 0,951 & Baik \\
& CFI & $\geq 0,95$ & 0,951 & Baik \\
\end{tabular}

Sumber: Data Primer (Diolah), 2019

Berdasarkan Tabel 3 di atas dapat dilihat nilai $X^{2}$ hitung sebesar 130,863. Sedangkan nilai $X^{2}$ tabel pada df $=87$ sebesar 104,773. Dengan kata lain, nilai $X^{2}{ }_{\text {hit }}>X^{2}$ tab $(130,863<104,773)$. Hal ini berarti bahwa nilai statistik $X^{2}$ hitung belum memenuhi kriteria yang telah ditentukan, sehingga model dinyatakan belum memenuhi ketentuan goodness of fit. Nilai probability atau p-value hasil measurement model pada tahap pertama ini sebesar 0,002 juga belum memenuhi kriteria yang telah ditentukan yakni di atas 0,05. Selanjutnya berdasarkan kriteria nilai GFI juga belum memenuhi syarat yakni sebesar 0,875 lebih kecil dari nilai yang dipersyaratkan sebesar 0,90. Demikian juga halnya dengan nilai AGFI sebesar 0,827 juga lebih kecil dari 0,90. Nilai TLI dan RMSEA juga sudah memenuhi persyaratan yakni masing-masing sebesar $0,9958(>0,95)$ dan $0,064(<0,08)$. Namun nilai CFI sebesar 0,949 belum memenuhi syarat karena lebih kecil dari nilai yang dipersyaratkan sebesar 0,950. Selanjutnya pada measurement model tahap kedua diperoleh nilai $X^{2}$ hitung sebesar 84,125 dengan $\mathrm{df}=74$. Nilai $\mathrm{X}^{2}$ tabel pada tingkatan df tersebut sebesar 95,081 lebih besar dibandingkan dengan nilai X2 hitung. Hal ini bearti bahwa ketentuan goodness of fit berdasarkan nilai X2 hitung sudah terpenuhi. Selanjutnya nilai statistik untuk kriteria lainnya seperti $\mathrm{p}$ value, GFI, AGFI, CFI, TLI dan RMSEA juga sudah memenuhi nilai yang dipersyaratkan. Sehingga langkah berikutnya dapat dilanjutkan ke full structural model guna menguji hubungan kausalitas antar variabel sesuai dengan paradigma penelitian yang telah dibuat sebelumnya.

\section{Full Structural Model}

Setelah measurement model yang dianalisis melalui analisis faktor konfirmatori dan ketahui bahwa masing-masing indikator dapat digunakan untuk mendefinisikan sebuah konstruk laten, maka langkah 
Dhian Wahyuni dan Ihsanuddin, Perceived Value dan Loyalitas Pengguna Kartu Kredit: Peran Kepuasan Sebagai Variabel Pemediasi

selanjutnya dalam penggunaan Structural Equition Model (SEM) sebagai peralatan analisis data adalah melakukan uji struktural terhadap keseluruhan model. Dalam hal ini peneliti secara langsung melakukan uji keterkaitan antara seluruh variabel (konstruk) yang diteliti dengan melibatkan seluruh indikator pada masing-masing konstruk. Hasil full structural model yang menjelaskan keterkaitan antara seluruh variabel penelitian seperti terlihat dalam Gambar 3.

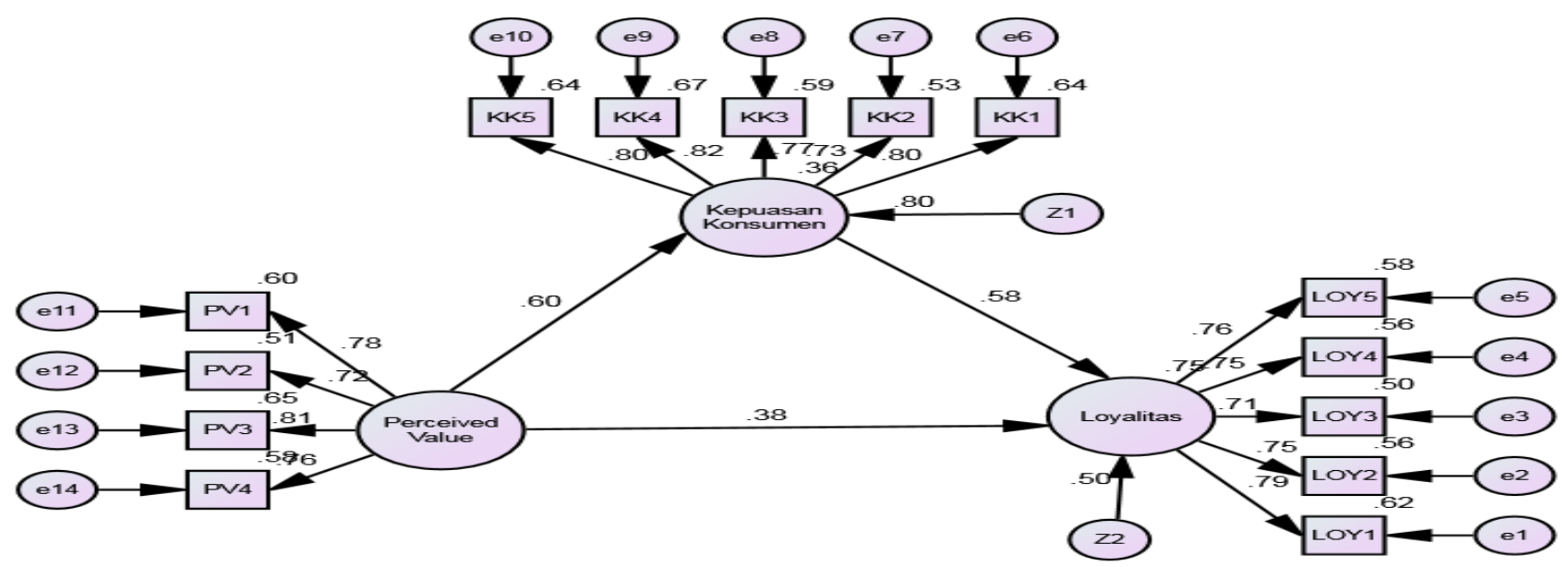

Gambar 3.

Hasil Full Structural Model

Gambar 3 di atas tidak hanya memperlihatkan nilai koefisien estimasi masing-masing variabel eksogen terhadap variabel endogen, tetapi juga memperlihatkan nilai loading factor masing-masing indikator (manifest variable) terhadap variabel tersebut Nilai koefisien estimasi perceived value terhadap kepuasan dan loyalitas pengguna kartu kredit seperti dalam Tabel 3.

Tabel 3.

Koefisien Estimasi Masing-masing Variabel

\begin{tabular}{llllll}
\hline & & & Estimate & C.R. & P \\
\hline Kepuasan_Konsumen & $<---$ & Perceived_Value & .602 & 5.689 & $* * *$ \\
Loyalitas & $<---$ & Kepuasan_Konsumen & .583 & 5.590 & $* * *$ \\
Loyalitas & $<---$ & Perceived_Value & .379 & 3.892 & $* * *$ \\
\hline
\end{tabular}

Sumber : Data Primer (Diolah), $2019 * * *=0,001$

Berdasarkan Tabel 3 di atas dapat dipahami bahwa perceived value berpengaruh positif terhadap kepuasan pengguna kartu kredit. Selain itu, kepuasan juga berpengaruh secara langsung terhadap loyalitas pengguna. Sehingga keberadaan kepuasan dapat dimaknai sebagai variabel intervening (perantara) antara perceived value di satu sisi dengan loyalitas pengguna kartu kredit di sisi lain. Dengan kata lain, pengaruh perceived value terhadap loyalitas tidak hanya terjadi secara langsung, tetapi juga melalui kepuasan sebagai variabel perantara.

\section{Analisis Pengaruh Perceived Value terhadap Kepuasan dan Loyalitas Pengguna Kartu Kredit}

Perceived value secara positif berpengaruh terhadap kepuasan pengguna kartu kredit dengan nilai koefisien estimasi sebesar 0,602 dengan $p$-value sebesar 0,001 $(<0,05)$. Berdasarkan nilai koefisien tersebut secara statistik dapat diartikan bahwa pengaruh langsung perceived value terhadap kepuasan pengguna sebesar 36,24 persen. Hal ini berarti bahwa semakin baik perceived value semakin tinggi kepuasan pengguna kartu kredit. Dengan kata lain, semakin baik nilai yang dipersepsikan oleh pengguna kartu kredit sehubungan dengan keberadaan kartu kredit, semakin tinggi pula kepuasan mereka dalam menggunakan kartu kredit tersebut. Dengan demikian hipotesis pertama $\left(\mathrm{H}_{1}\right)$ yang menyatakan Perceived value berpengaruh terhadap kepuasan pengguna kartu kredit dapat diterima. Temuan ini mendukung hasil kajian sebelumnya yang dilakukan oleh Deghan et al. (2015) yang memberikan bukti empiris bahwa perceived value secara positif dan signifikan berpengaruh terhadap kepuasan konsumen. Hasil kajian Dehghan et al. 
Dhian Wahyuni dan Ihsanuddin, Perceived Value dan Loyalitas Pengguna Kartu Kredit: Peran Kepuasan Sebagai Variabel

(2015) juga memberikan kesimpulan yang sama bahwa kepuasan konsumen secara signifikan dipengaruhi oleh perceived value yang ada dalam diri konsumen tersebut sehubungan dengan keberadaan produk dan jasa yang mereka gunakan.

Perceived value juga berpengaruh positif dan signifikan terhadap loyalitas pengguna kartu kredit. Hal ini ditunjukkan oleh koefisien estimasi sebesar 0,379 p-value sebesar 0,001 $(<0,05)$. Pengguna kartu kredit dengan perceived value relatif lebih tinggi cenderung memiliki loyalitas lebih tinggi dibandingkan mereka dengan perceived value relatif lebih rendah. Hal ini mengindikasikan adanya hubungan searah antara kedua variabel tersebut. Mengacu pada nilai koefisien estimasi di atas, maka pengaruh langsung perceived value terhadap loyalitas sebesar 14,36 persen. Angka ini lebih kecil bila dibandingkan dengan pengaruh langsung perceived value terhadap kepuasan sebesar 36,24 persen. Dengan kata lain, dampak positif perceived value terhadap peningkatan kepuasan lebih besar bila dibandingkan dengan dampaknya terhadap peningkatan loyalitas pengguna. Berdasarkan penjelasan tersebut, maka hipotesis kedua $\left(\mathrm{H}_{2}\right)$ yang menyatakan perceived value berpengaruh terhadap loyalitas pengguna kartu kredit dapat diterima. Adanya pengaruh positif perceived value terhadap loyalitas sejalan dengan hasil penelitian Picon-Berjoyo et al. (2016) bahwa perceived value berpengaruh positif dan signifikan terhadap loyalitas keperilakuan. Sebelumnya penelitian Khan \& Kadir (2011) juga memberikan kesimpulan yang sama bahwa intensi berperilaku yang dimanifestasikan dalam loyalitas keperilakuan dipengaruhi oleh perceived value.

\section{Analisis Pengaruh Kepuasan terhadap Loyalitas Pengguna Kartu Kredit}

Kepuasan konsumen berpengaruh positif terhadap loyalitas pengguna kartu kredit dengan koefisien estimasi sebesar 0,583 dan p-value sebesar 0,001 $(<0,005)$. Semakin tinggi kepuasan mereka sehubungan dengan pemanfaatan kartu tersebut untuk kepentingan transaksi semakin tinggi pula loyalitas. Sebaliknya, penurunan kepuasan berdampak pada penurunan loyalitas pengguna kartu kredit. Pengaruh langsung kepuasan konsumen terhadap loyalitas pengguna sebesar 33,99 persen. Dengan emikian hipotesis ketiga $\left(\mathrm{H}_{3}\right)$ yang menyatakan kepuasan berpengaruh terhadap loyalitas pengguna kartu kredit dapat diterima. Temuan ini konsisten dengan hasil penelitian hasil penelitian Khan \& Kadir (2011) dan Dehghan et al. (2015) bahwa kepuasan secara positif dan signifikan meningkatkan loyalitas konsumen. Pengguna kartu kredit yang puas dalam pengunaan kartu tersebut akan memiliki loyalitas yang tinggi dibandingkan dengan mereka yang kurang puas. Sebagaimana temuan penelitian Beerli et al. (2014) yang menyimpulkan bahwa kepuasan merupakan pembentuk utama tingkat loyalitas konsumen.

\section{Peran Kepuasan Sebagai Pemediasi antara Perceived Value dan Loyalitas Pengguna Kartu Kredit}

Berdasarkan kaedah analisis jalur, pengaruh tidak langsung suatu variabel terhadap variabel lainnya dicari dengan mengalikan koefisien estimasi antar variabel. Sebagaimana dijelaskan sebelumnya, koefisien estimasi perceived value terhadap kepuasan konsumen sebesar 0,602. Selanjutnya koefisien jalur kepuasan konsumen terhadap loyalitas pengguna kartu kredit sebesar 0,583. Dengan demikian pengaruh tidak langsung perceived value terhadap loyalitas melalui kepuasan konsumen sebesar 35,10 persen. Angka ini lebih besar bila dibandingkan dengan pengaruh langsung perceived value terhadap loyalitas pengguna kartu kredit sebesar 14,36 persen. Dengan demikian dapat diartikan keberadaan kepuasan konsumen memperkuat pengaruh perceived value terhadap loyalitas pengguna kartu kredit di kota Banda Aceh. Secara matematis deskripsi kuantitatif berkaitan dengan pengaruh langsung dan tidak langsung perceived value terhadap loyalitas pengguna kartu kredit ditunjukkan pada tabel 4.

Tabel 4.

Perbandingan Pengaruh Langsung dan Pengaruh Tidak Langsung antar Variabel

\begin{tabular}{|c|c|c|c|}
\hline Bentuk Pengaruh & Arah Pengaruh & $\begin{array}{l}\text { Koefisien } \\
\text { Estimasi }\end{array}$ & $\begin{array}{l}\text { Besarnya } \\
\text { Pengaruh }\end{array}$ \\
\hline \multirow[t]{3}{*}{ Pengaruh langsung } & Perceived value terhadap kepuasan pengguna kartu kredit & 0,602 & $36,24 \%$ \\
\hline & Perceived value terhadap loyalitas pengguna kartu kredit & 0,379 & $14,36 \%$ \\
\hline & Kepuasan terhadap loyalitas pengguna kartu kredit. & 0,583 & $33,99 \%$ \\
\hline Pengaruh tidak langsung & $\begin{array}{l}\text { Perceived value terhadap loyalitas melalui kepuasan pengguna } \\
\text { kartu kredit }\end{array}$ & 0,602 dan 0,583 & $35,10 \%$ \\
\hline
\end{tabular}

Sumber : Data Primer (Diolah), 2019 
Pengujian efek mediasi kepuasan konsumen dalam memediasi pengaruh perceived value terhadap loyalitas merujuk pada pendapat Baron dan Kenny (1986) dengan mengoperasionalkan tiga tahapan regresi. Hasil regresi tahap pertama menunjukkan bahwa pengaruh perceived value terhadap kepuasan konsumen signifikan dengan nilai p-value sebesar 0,001. Selanjutnya hasil regresi tahap kedua menunjukkan bahwa perceived value terhadap loyalitas pengguna kartu kredit juga signifikan dengan nilai p-value sebesar 0,001. Selanjutnya hasil regresi tahap ketiga yakni menguji pengaruh perceived value dan kepuasan konsumen secara bersamaan terhadap loyalitas juga menunjukkan bahwa kedua variabel tersebut berpengaruh signifikan dengan nilai p-value masing-masing sebesar 0,001 . Guna memudahkan analisis tentang pengujian efek mediasi kepuasan konsumen sebagai variabel perantara antara perceived value dan loyalitas pengguna kartu kredit dapat dilihat Gambar 4.

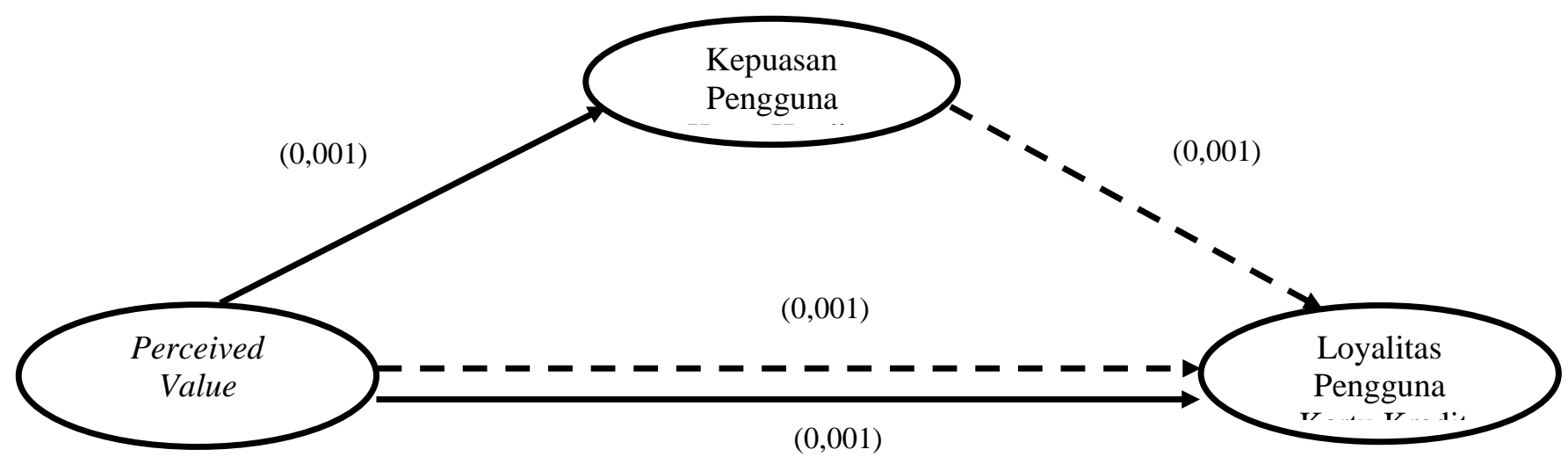

Gambar 4

Pengujian Efek Mediasi Kepuasan Sebagai Variabel Perantara

Antara Perceived Value dan Loyalitas Pengguna Kartu Kredit

Keterangan : Angka dalam ( ) adalah nilai $p$-value

Berdasarkan Gambar 4 di atas dapat dilihat bahwa pengaruh perceived value terhadap kepuasan konsumen signifikan, dan pengaruh kepuasan konsumen terhadap loyalitas juga signifikan. Demikian pula halnya dengan pengaruh langsung perceived value dan kepuasan konsumen secara bersamaan terhadap loyalitas, juga signifikan. Dengan demikian dapat diartikan bahwa efek mediasi kepuasan konsumen sebagai perantara antara loyalitas pengguna kartu kredit dan perceived value adalah mediasi parsial. Berdasarkan penjelasan di atas, maka hipotesis $\mathrm{H}_{4}$ yang menyatakan, perceived value berpengaruh terhadap loyalitas pengguna kartu kredit melalui kepuasan sebagai variabel pemediasi dapat diterima. Temuan ini mendukung temuan penelitian Picon-Berjoyo et al. (2016) bahwa kepuasan konsumen memperkuat pengaruh perceived value terhadap loyalitas. Hasil kajian ini juga konsisten dengan sejumlah hasil penelitian lain seperti Lam et al., (2014), Lin et al. (2015) dan Picon et al. (2014) yang membuktikan adanya peran kepuasan konsumen dalam memediasi hubungan sebab akibat antara perceived value dan loyalitas konsumen.

\section{SIMPULAN}

Perceived value secara positif dan signifikan berpengaruh terhadap loyalitas pengguna kartu kredit bank umum di kota Banda Aceh. Semakin tinggi perceived value semakin tinggi pula kepuasan konsumen dan pada gilirannya berdampak pada peningkatan loyalitas pengguna kartu kredit. Sebaliknya, penurunan perceived value berdampak pada penurunan kepuasan konsumen sehingga loyalitas pengguna kartu kredit menjadi semakin menurun. Perceived value secara positif juga berpengaruh terhadap loyalitas pengguna kartu kredit melalui kepuasan sebagai variabel pemediasi. Pengaruh tidak langsung perceived value terhadap loyalitas pengguna kartu kredit melalui kepuasan konsumen lebih besar bila dibandingkan dengan pengaruh langsungnya. Dengan demikian dapat disimpulkan bahwa keberadaan kepuasan konsumen dapat memperkuat pengaruh perceived value terhadap loyalitas pengguna kartu kredit. Efek mediasi yang dimunculkan oleh kepuasan dalam memediasi pengaruh kedua variabel tersebut adalah mediasi parsial. 
Dhian Wahyuni dan Ihsanuddin, Perceived Value dan Loyalitas Pengguna Kartu Kredit: Peran Kepuasan Sebagai Variabel Pemediasi

\section{DAFTAR PUSTAKA}

Amri, K. 2013. Faktor-Faktor Yang Mempengaruhi Loyalitas Konsumen Surat Kabar Harian Serambi Indonesia di Kota Banda Aceh, Jurnal Ekonomi Manajemen dan Bisnis, 1(2), 229-242.

Amri, K., \& Nazamuddin. 2018. Is there causality relationship between economic growth and income inequality? Panel data evidence from Indonesia, Eurasian Journal of Economics and Finance, 6 (2), 8-20.

Amri, K., \& Surya, J. 2013. Kajian Perilaku Mahasiswa Dalam Menggunakan Internet Dengan Pendekatan Technology Acceptance Model (TAM), Jurnal Penelitian Pos dan Informatika 3 (1), 67-80.

Amri, K., Qurratul'aini, I., \& Julianty. 2018. Preferensi Nasabah Memilih Produk Pembiayaan Bank Aceh Syariah di Kota Banda Aceh, Jurnal Samudra Ekonomi dan Bisnis 9(1), 31-41.

Anuwichanont, J., \& Mechinda, P. 2016. The Impact of Perceived Value on Spa Loyalty and Its Moderating Effect of Destination Equity, Journal of Business \& Economics Research 7(12), 75-90.

Asy'ari, A. H. 2014. Pengaruh Value dan Trust Terhadap Behavioral Loyalty (Studi Pada Konsumen Sepeda Motor Honda di Banjarmasin), Kindai, 10(1), 1-12.

Ball, D., Coelho, P. S., \& Machas, A. 2004. The role of communication and trust in explaining customer loyalty an extension to the ECSI model. European Journal of Marketing, 38(9), 1272-1293.

Baron, R.M., and Kenny, D.A. 1986. The Moderator-Mediator Variable Distinction in Social Psychological Research: Conceptual, Strategic, and Statistical Considerations, Journal of Personality and Social Psychology, 51(6),1173-1182.

Beerli, A., Martín, J., \& Quintana, A. 2014. A model of customer loyalty in the retail banking market. European Journal of Marketing, 38, 253-275.

Darsono, Licen Indahwati, 2014, Loyalty \& Disloyalty: Sebuah Pandangan Komprehensif Dalam Analisis Loyalitas Pelanggan, Jurnal Kinerja, 8(2),163-173.

Dehghan, N. A., Alizadeh, H., \& Mirzaei-Alamouti, S. 2015. Exploring the customer perceived values as Antecedent of purchase behavior, Serbian Journal of Management, 10(2), 173-188.

Forouzandeh, S., \& Ahmadi, P. 2010. Maintaining customer loyalty in a deregulating service industry. International Bulletin of Business Administration, 8(3), 221-234.

Ghozali, Imam 2011 Structural Equition Modelling, Metode Alternatif Dengan Partial Least Square PLS, Badan Penerbit Universitas Diponegoro, Semarang.

Giddens, N., \& Hofmann, A. 2012, Brand Loyalty. (online) http://www. extension.iastate.edu/agdm/wholefarm. diakses 11 Februari 2017

Khan, N., \& Kadir, S. L. S. A. 2011. The impact of perceived value dimension on satisfaction and behavior intention: Young-adult consumers in banking industry, African Journal of Business Management, 5 (11), 4087-4099.

Kotler, P., dan Keller, K. L. 2016. Manajemen Pemasaran. Edisi Kedua Belas Jilid 1, Penerbit PT. Indeks, Jakarta.

Koupai, M. R., Alipourdarvish, Z., \& Sardar, S. 2015. Effects of trust and Perceived value on customer loyalty by mediating role of customer satisfaction and mediating role of customer habit (case study: Agricultural internet bank customers in Tehran), Advanced Social Humanities and Management 2(1), 102-112

Lam, S. Y., Shankar, V., Erramilli, M. K., \& Murthy, B. 2014. Customer value, satisfaction, loyalty, and switching costs: An illustration from a businessto business service context. Journal of the Academy of Marketing Science, 32(3), 293-311.

Lin, C. H., Sher, P. J., \& Shih, H. Y. 2015. Past progress and future directions in conceptualizing customer perceived value. International Journal of Service Industry Management, 16(4), 318-336.

Neal, W. D. 2010. Loyalty Really Isn't All That Simple, Restrictive, Marketing News.

Oliver, R. L. 2017. Satisfaction: A Behavioral Perspective on The Consumer. New York: The McGraw-Hill Companies. Inc

Picon, A., Castro, I., \& Roldan, J. L. 2014. The relationship between satisfaction and loyalty: A mediator analysis. Journal of Business Research, 67,746-751.

Picon-Berjoyo, A., Ruiz-Moreno, C., \& Castro, I. 2016. A mediating and multigroup analysis of customer loyalty. European Management Journal 12, 1-13. 
Dhian Wahyuni dan Ihsanuddin, Perceived Value dan Loyalitas Pengguna Kartu Kredit: Peran Kepuasan Sebagai Variabel Pemediasi

Schiffman, L G and Kanuk LL., 2014, Consumer Behavior, Sevent Edition, New Jersey, Prentice Hall International.

Shanmugam, A., Savarimuthu, M. T., \& Wen, T. C. 2014. Factors affecting Malaysian behavioral intention to use mobile banking with mediating effects of attitude, Academic Research International, 5(2), 236-253.

Yang, Z., \& Petterson, R. T, 2014. Customer perceived value, satisfaction, and loyalty: The role of switching costs. Psychology and Marketing, 21, 799-822. 